\title{
Transforming Undergraduate STEM Summer Internships in a Federal Gov- ernment Institution for 21st Century Engineering Careers
}

\section{Dr. Mary Yvonne Lanzerotti, Air Force Institute of Technology}

Dr. Lanzerotti is an Associate Professor of Computer Engineering at the Air Force Institute of Technology. She received degrees from Harvard University, University of Cambridge (UK), and Cornell University.

\section{Ms. Maggie Varga, SOCHE}

Maggie Varga, Director, Southwestern Ohio Council for Higher Education (SOCHE)

Maggie Varga is a Director for the Southwestern Ohio Council for Higher Education (SOCHE). In her capacity as Director, Maggie leads the SOCHEIntern Program, which employs nearly 300 students annually in cooperation with local government and small businesses, as well as the Air Force Institute of Technology (AFIT) and Air Force Research Laboratory (AFRL) at Wright-Patterson Air Force Base. The program provides high impact experiential learning opportunities for students while generating economic benefit and enhancing community sustainability. Her work improves the efficiency of programs that support member institutions and increase the success of more than 120,000 students in southwest Ohio. Maggie has also provided guidance and leadership in the creation and evolution of regional initiatives such as the Dayton Water Roundtable, Ohio's Great Corridor Association, and the University of Dayton Rivers Institute.

Prior to her position at SOCHE, Maggie worked for the Fitz Center for Leadership in Community at the University of Dayton.

Maggie has a Master of Business Administration and a Bachelor of Science in Economics and Finance from the University of Dayton.

\section{Dr. Sean J Creighton, SOCHE}

Sean Creighton is the Executive Director of SOCHE, a regional consortium of colleges and universities dedicated to educating, employing, and engaging citizens. In 2012, SOCHE received the Dayton Business Journal Non-Profit Business of the Year Award.

Sean is an elected member of the Board of Education for the Yellow Springs Public Schools, and serves on advisory committees for several local and national organizations. He has published and presented extensively on the impact of higher education, collaboration and civic engagement, and has conducted research for the Kettering Foundation on the economic and civic missions of regionally based colleges and universities.

Sean has degrees from Marist College and New York University, and earned his PhD from Antioch University. He lives in the charming village of Yellow Springs with his wife, Leslee, and his five fun children, Liam, Maya, Quinn, Audrey, and Juliette.

\section{Dr. Derrick Langley, Air Force Institute of Technology}

Derrick Langley is an Assistant Professor of Electrical Engineering at the Air Force Institute of Technology (AFIT), Wright-Patterson Air Force Base (AFB), Ohio. He received his B.S. in electrical engineering from the University of Central Florida in 2003, his M.S. in electrical engineering from Wright State University in 2007, and his Ph.D. in electrical engineering from AFIT, Wright-Patterson AFB in 2012. His current research interests are metamaterials, microelectronics, microelectromechanical systems and nanotechnology.

Mrs. Diana Lynn Cahill, Air Force Institute of Technology

Mrs. Diana Lynn Cahill, Air Force Institute of Technology

M.Ed., Curriculum and Instruction, Wright State University B.A., English, Youngstown State University 
Ohio Teaching License, High School, English

Current Position- Civilian Student Coordinator, Air Force Institute of Technology, Wright-Patterson Air Force Base.

\section{Dr. Richard K. Martin, The Air Force Institute of Technology}

Richard K. Martin received dual B.S. degrees (summa cum laude) in physics and electrical engineering from the University of Maryland, College Park, in 1999 and the M.S. and Ph.D. degrees in electrical engineering from Cornell University, Ithaca, NY, in 2001 and 2004, respectively. Since August 2004, he has been with the Department of Electrical and Computer Engineering, Air Force Institute of Technology (AFIT), Dayton, OH, where he is an Associate Professor. He is the author of 29 journal papers and 56 conference papers, and he holds five patents. His research interests include radio tomographic imaging; navigation and source localization; and laser radar. Dr. Martin has been elected Electrical and Computer Engineering Instructor of the Quarter three times and HKN Instructor of the Year twice by the AFIT students. He is currently serving as an Associate Editor for IEEE Signal Processing Letters and a Guest Editor for the IEEE Journal of Selected Topics in Signal Processing. 


\title{
Transforming Undergraduate STEM Summer Internships in a Federal Government Institution for $21^{\text {st }}$ Century Engineering Careers
}

\begin{abstract}
This paper describes first steps to transform all internships in the undergraduate STEM Summer Research Program in the federal government at the Air Force Institute of Technology (AFIT) to prepare students for engineering careers in the $21^{\text {st }}$ century. AFIT is a government institution of higher education within the Air Force. Over 40 students participate annually and perform research in all six engineering departments at the AFIT Graduate School of Engineering and Management. These are the departments of Aeronautics and Astronautics, Electrical and Computer Engineering, Engineering Physics, Mathematics and Statistics, Operational Sciences, and Systems Engineering and Management.
\end{abstract}

First, starting in summer 2012, a formal assessment tool is now distributed to students to measure the impact of the research experience. Second, starting in summer 2013, students are now provided with four career broadening programs that are informed by student survey results in 2012. These programs are made possible through a partnership among AFIT, the LEADER (Launching Equity in the Academy across the Dayton Entrepreneurial Region) Consortium, and the Southwestern Ohio Consortium for Higher Education (SOCHE). The partnership assesses the students' experiences and informs future experiences based upon the results of student surveys. SOCHE has employed nearly 1,000 STEM students in the past 25 years.

Feedback was sought in 2012 from the 48 participating students to improve all internships in the Summer Research Program in order to help prepare engineering student interns for work in the $21^{\text {st }}$ century. In response to the feedback, four new voluntary program components were made available to all students in the 2013 Program. Because of government restrictions, student participation is voluntary. The components are: (A) A joint orientation process with SOCHE and AFIT Project Leaders; (B) Student cohorts through social activities and STEM-based games; (C) A weekly seminar meeting with outside presentations of general interest, such as job-hunting, resume-writing, information about scholarships and fellowships, and the process to apply to graduate school; and (D) A Poster Session so that students present the engineering experiences they have gained. A poster competition was held to select the best student posters, and selected students were awarded "Posters of Excellence" Certificates.

In 2013, SOCHE again implemented an assessment tool in an effort to better understand the needs of the 43 participating students. Of these students, 10 students had also participated in the 2012 program (repeat participation rate of nearly 25\%). SOCHE asked all 43 students to complete a pre survey when the program was in session (response rate: $33 \%$ ) and a post survey following the program (response rate: 16\%). Post survey responses are favorable to the career broadening programs. Student participation in the 12 one-hour weekly events was nearly $100 \%$ in the joint orientation and $13 \%$ in the other events. 
This paper will describe the importance of the four new career-broadening components to transform the internships at AFIT to prepare students for engineering careers in the $21^{\text {st }}$ century. Additional results and findings of the assessment of the 2013 Summer Research Program will be discussed, and the results and findings will be compared with results from the 2012 Program.

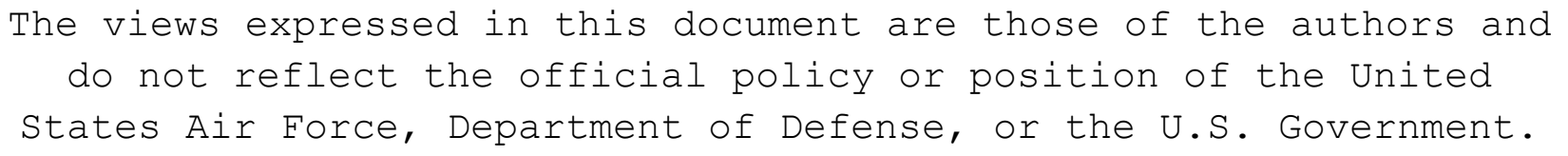




\section{Introduction}

To meet the technology needs of our increasingly complex global society, engineers in the $21^{\text {st }}$ century are now expected to exhibit key attributes to ensure their success and the success of the engineering profession, according to the National Academy of Sciences in their groundbreaking 2004 report entitled The Engineer of 2020: Visions of Engineering in the New Century. These attributes are identified as strong analytical skills, practical ingenuity, creativity, communication, business and management, leadership, high ethical standards, professionalism; dynamism, agility, resilience, and flexibility, and becoming lifelong learners. ${ }^{1}$

This project is motivated by the results and findings of our initial assessment of the Air Force Institute of Technology (AFIT) Summer Research Program (published in 2013 ASEE Annual Meeting $^{2}$ ) and a series of reports published by the National Academy during the past decade entitled The Engineer of 2020: Visions of Engineering in the New Century, Rising Above the Gathering Storm and Examination of the U.S. Air Force's Science, Technology, Engineering, and Mathematics Workforce Needs in the Future and Its Strategy to Meet Those Needs. The approach of our current project to transform the undergraduate STEM summer internships at AFIT is to expose a pool of STEM undergraduate students to research opportunities and future educational opportunities at a DOD institution of the federal government. Through this exposure, the students will be motivated to graduate with STEM degrees and will acquire skills to help them be successful in $21^{\text {st }}$ century engineering careers. Another outcome of this exposure is that it increases the number of civilian students who have the opportunity to develop unique capabilities and current skills that are aligned with the workforce needs of the Air Force.

It is well known that "a strong U.S. science and engineering workforce is of clear interest to the DOD, as the capability of producing superior technology is essential for future national security." ${ }^{3}$ The federal government offers opportunities to undergraduates and summer undergraduate interns in engineering careers through the following opportunities. The National Science Foundation offers undergraduate research programs at civilian institutions through a "Research Experiences for Undergraduates" (REU) program. ${ }^{4}$ Fellowship and scholarship opportunities that include research internships offered at a DOD government institution include:

- SMART Scholarship Program that "encourages students pursuing degrees in the Science, Technology, Engineering, and Mathematics (STEM) disciplines to apply for Science, Mathematics, and Research for Transformation (SMART) scholarships. In addition to tuition and other educational expenses, SMART participants receive a generous cash award, health insurance allowance, and summer internships at AFCS facilities.",5,6

- National Defense Science and Engineering Graduate (NDSEG) Fellowship program, which are "awarded to applicants to will pursue a doctoral degree in, or closely related to, an area of DoD interest within one of the fifteen following disciplines: Aeronautical and Astronautical Engineering, Biosciences, Chemical Engineering, Chemistry, Civil Engineering, Cognitive, Neural, and Behavioral Sciences, Computer and Computational Sciences, Electrical Engineering, Geosciences, Materials Science and Engineering, Mathematics, Mechanical Engineering, Naval Architecture and Ocean Engineering, Oceanography, and Physics."7 
Research and scholarship opportunities offered by the U.S. Air Force (USAF) to develop $21^{\text {st }}$ century engineers include:

- Air Force Summer Research Program, ${ }^{8}$ which is the subject of this paper at a DOD Institution, and which offers internships to undergraduates majoring in engineering (aeronautical, astronautical, electrical and computer, mechanical, nuclear, and systems) and science (computer science, materials science, mathematics, operations research, and physics);

- Year-round Internship Program, ${ }^{9}$ which is also held at this DOD institution during the school year and is offered to students majoring in engineering and science (the disciplines listed above);

- Pathways Internship Program, which "provides students with paid opportunities to work and explore Federal careers while still in school. This includes the Summer Hire Program....;",9,10

- PALACE Acquire, which "offers [students] the opportunity to occupy a permanent fulltime position during a 2-4 year, formal training plan design to let [the student] experience both personal and professional growth while dealing effectively and ethically with change, complexity, and problem solving." Career fields in this program include civil engineering, communications and information, intelligence, logistics, program management, security, and science and engineering; ${ }^{11}$

- Summer Faculty Fellowship Program (SFFP), ${ }^{12}$ in which a faculty member who is a U.S. citizen can bring a graduate student (who is also a U.S. citizen) to a DOD institution, including the institution participating in this current paper, for research during 8-10 weeks during the summer. The research interests are aligned with the interests and needs of the nine Air Force Research Laboratory Directorates, Air Force Test Center, the U.S. Air Force Academy, and the Air Force Institute of Technology.

- Air Force Office of Scientific Research (AFOSR) Awards to Stimulate and Support Undergraduate Research Experiences (ASSURE), which is similar to the NSF Research Experiences for Undergraduates (REU) program. ${ }^{3}$ The ASSURE program "supports undergraduate research in DOD relevant disciplines and is designed to increase the number of high-quality undergraduate science and engineering majors who ultimately decide to pursue advanced degrees in these fields."

- NSF Federal Cyber Service: Scholarship for Service (SFS) Program. This program "is a unique program designed to increase and strengthen the cadre of federal information assurance professionals that protect the government's critical information infrastructure. This program provides scholarships that may fully fund the typical costs incurred by fulltime students while attending a participating institution.,"13,14

Research and internship opportunities offered by the Department of Energy (DOE) include Oak Ridge Institute for Science and Education (ORISE), which "directly supports DOE's national agenda to advance science education and research programs by creating opportunities for 
collaboration through partnerships with DOE facilities, other federal agencies, the academic community, and industry":

- Oak Ridge Institute for Science and Education (ORISE), which matches students which research opportunities at research facilities at national laboratories located around the United States. ${ }^{15}$ This program is "a national leader in science education and research" and was established as "an official U.S. Department of Energy (DOE) institute in 1992."15

This paper describes first steps to transform all internships in the undergraduate STEM Summer Research Program in the federal government at the Air Force Institute of Technology (AFIT) to prepare students for engineering careers in the $21^{\text {st }}$ century. In these first steps, we introduce additional components to an existing summer research program specifically to develop the key attributes of strong analytical skills, communication, high ethical standards, and professionalism that are desired in $21^{\text {st }}$ century engineers.

Over 40 students participate annually and perform research in all six engineering departments at the AFIT Graduate School of Engineering and Management. These are the departments of Aeronautics and Astronautics, Electrical and Computer Engineering, Engineering Physics, Mathematics and Statistics, Operational Sciences, and Systems Engineering and Management.

First, starting in summer 2012, a formal assessment tool is now distributed to students to measure the impact of the research experience. ${ }^{2}$ Second, starting in summer 2013, students are now provided with four career broadening programs that are informed by student survey results in 2012. These programs are made possible through a partnership among AFIT, the LEADER (Launching Equity in the Academy across the Dayton Entrepreneurial Region) Consortium, and the Southwestern Ohio Consortium for Higher Education (SOCHE). The partnership assesses the students' experiences and informs future experiences based upon the results of student surveys.

In 2012, feedback was sought from the 48 participating students to improve all internships in the Summer Research Program in order to help prepare engineering student interns for work in the $21^{\text {st }}$ century. In response to the feedback, four new voluntary program components were made available to all students in the 2013 Program as described in this paper (because of government restrictions, student participation is voluntary.) The components are:

(A) A joint orientation process with SOCHE and AFIT Project Leaders;

(B) Student cohorts through social activities and STEM-based games;

(C) A weekly seminar meeting with outside presentations of general interest, such as jobhunting, resume-writing, information about scholarships and fellowships, and the process to apply to graduate school; and

(D) A Poster Session so that students present the results of the engineering experiences they have gained. The Poster Session is open to members of the public as well as to members of the DOD (faculty, students, and staff). 
These four components are designed to provide students with the opportunity to develop and exhibit strong analytical skills, communication, high ethical standards, and professionalism through written and oral presentations and discussions with fellow students, industry experts, and faculty.

In 2013, SOCHE again implemented an assessment tool in an effort to better understand the needs of the 43 participating students. Of these students, 10 students had also participated in the 2012 program (repeat participation rate of nearly 25\%). SOCHE asked all 43 students to complete a pre survey when the program was in session (response rate: $33 \%$ ) and a post survey following the program (response rate: 16\%). Post survey responses are favorable to the career broadening programs. Student participation in the 12 one-hour weekly events was nearly $100 \%$ in the joint orientation and $13 \%$ in the other events.

In 2013 for the first time, SOCHE asked the 10 students who participated in both the 2012 program and in the 2013 program to complete an additional "Rehire Survey" (response rate: $60 \%$ ). Rehire survey responses are favorable, and these results are also discussed in this paper.

The goal of this paper is to describe the importance of the four new career-broadening components to transform the internships at AFIT to prepare students for engineering careers in the $21^{\text {st }}$ century. In this paper, we discuss how each of the components provides students with the opportunity to develop and exhibit the key attributes of strong analytical skills,

communication, high ethical standards, and professionalism. We also present and discuss new results and findings of the assessment of the 2013 Summer Research Program, and we compare these new results and findings with previous results from the 2012 Program. Finally, we describe steps that the partners will take in future summer research programs, starting in 2014, to try to increase the participation of the undergraduates in the four components in the program (since participation is voluntary).

\section{Motivation}

Many challenges existed at a government institution to introduce standard STEM program components to a long-standing summer research program. In our prior work, ${ }^{2}$ the partners AFIT, SOCHE, and the LEADER Consortium presented a unique campus-community partnership that successfully introduced a new paradigm to the AFIT Summer Research Program. With this paradigm, the three partners found a way forward together to upgrade the AFIT Summer Research Program based on student recommendations. These standard STEM program components now offer students for the first time, to our knowledge in the 2013 Summer Research Program. Student participation is completely voluntary. Prior research presented at 2013 ASEE described a new paradigm that upgraded the summer program with the inclusion of four components to provide better research experiences for the students.

In this project, the partners are motivated to improve the summer research experiences of the students in order to motivate the undergraduates to complete their STEM degrees in order to contribute to the $21^{\text {st }}$ century workforce in engineering fields. This paper will describe our efforts to improve the research experiences through the incorporation of four STEM components intended to improve the students' professional skills. 
As a federal government institution located on an operating military base, the incorporation of these four components offers the opportunity to the partners to bring unique opportunities to the participating students. As described below, these opportunities include participating in defensefocused research areas, learning about scholarship and fellowships related to defense, and learning from industry experts about methods to prepare their resume and $\mathrm{CV}$ effectively to future employers. These experts are drawn from the local region from companies who focus on providing career mentorship to the federal government and contractors.

\section{Partners}

The LEADER Consortium is funded by an ADVANCE Institutional Transformation Award from the NSF Award \#0810989 since 2008 and is a partnership of four institutions of higher education in the Dayton region: the Air Force Institute of Technology, Central State University, University of Dayton, and Wright State University. The LEADER Consortium was selected for an Award in Cohort 4 of the National Science Foundation's ADVANCE Institutional Transformation Program. ${ }^{15,16}$

The Air Force Institute of Technology (AFIT) is a purely graduate-level institution, and as such, it is one of the few institutions offering graduate-level ABET-accredited degrees. ${ }^{17}$ Out of roughly 800 students, $74 \%$ are $\mathrm{MS}, 16 \%$ are $\mathrm{PhD}$, and $10 \%$ are certificate or non-degree-seeking students. The enrollment is 73\% Air Force, 4\% sister services, 3\% international officers, and $20 \%$ civilian. AFIT's faculty members are approximately composed of $50 \%$ military faculty and $50 \%$ civilian faculty, and they are expected to conduct research programs in the same manner as civilian schools. AFIT's mission is to advance air, space, and cyberspace power for the Nation, its partners, and our armed forces by providing relevant defense-focused technical graduate and continuing education, research, and consultation. In 2011, the Carnegie Foundation identified AFIT as a doctoral/research institution for the first time in recognition of the doctoral education productivity with strong research activity in Science, Technology, Engineering, and Mathematics disciplines. Students participating in the AFIT Summer Research Program work with faculty in six departments: Aeronautics and Astronautics, Electrical and Computer Engineering, Engineering Physics, Mathematics and Statistics, Operational Sciences, and Systems and Engineering Management. These departments contain five centers: the Center for Cyberspace Research, Center for Directed Energy, Center for Operational Analysis, Center for Technical Intelligence Studies and Research, and Advanced Navigation Technology Center.

The Southwestern Ohio Council for Higher Education, or SOCHE, is a 501c3 non-profit organization. ${ }^{18}$ Formed in 1967, SOCHE is a regional consortium of 20 colleges and universities in southwest Ohio. SOCHE's mission is to be "the collaborative infrastructure for higher education, helping colleges and universities transform their communities and economies through the education, employment, and engagement of more than 120,000 students in southwest Ohio." In addition to providing internships, ${ }^{6}$ the organization manages a comprehensive portfolio of programs and initiatives to support higher education in the region. 


\section{Background}

As a review, in the 2012 Summer Research Program, we identified the following four broad needs expressed by the students based on the pre-survey and post-survey administered by SOCHE:

(1) A desire expressed by students for mentors with increased organization and communication among SOCHE, AFIT, and the students;

(2) A desire expressed by students for increased interactions with other students;

(3) A desire expressed by students to improve their CV/resume at the beginning of the program and interest expressed by students in applying for the SMART Scholarship;

(4) A desire expressed by students to gain engineering experience, skills, and confidence in research.

In response to student feedback, we spent the subsequent eight months following the 2012 Summer Research Program (September 2012 through April 2013) planning four additional components to address these four needs. To oversee all the students in 2013, AFIT again hired a Civilian Student Coordinator (one of our co-authors on this paper). First, to increase communication among SOCHE, AFIT, and the summer interns, we planned a joint orientation process with SOCHE and AFIT Project Leaders/Mentors.

Second, in 2013, to increase interactions among the students, our team developed student cohorts. The AFIT Civilian Student Coordinator, Mrs. Cahill, wrote a Civilian Student Survival Guide to share with students to improve the summer student experience. We prepared some general student social activities and created some STEM games in the hopes of fostering a sense of shared mission.

Third, we developed a regular seminar with three outside presentations of general interest, such as on job-hunting, resume-writing, information about scholarships and fellowships, and a poster creation workshop.

Fourth, since one of the more valuable skills that students can learn from open-ended projects is the opportunity to develop presentation and communication skills, we organized a small conference to present the students' work to the AFIT community so that students can present the engineering experiences they have gained.

\section{Introduction of Component \#1: Joint Orientation process with SOCHE and DOD Project Leaders}

The first component that we introduced in the 2013 Summer Research Program is a Joint Orientation. The purpose of this meeting is to introduce the undergraduates to the Director of SOCHE and to AFIT Project Leaders. As discussed previously, this component is designed to provide students with the opportunity to develop and exhibit communication and professionalism through oral presentations and discussions with fellow students and faculty. 
The date of the Joint Orientation for student interns was June 5, 2013, at the start of the summer program. The AFIT Civilian Student Coordinator held the Joint Orientation with SOCHE and DOD Project Leaders (also referred to as the Faculty Advisors) in a classroom at AFIT.

Attendees at the Joint Orientation included 26 of the 43 (response rate: 60\%) participating summer students, the Director of SOCHE, the Director of Student Services at AFIT, the Civilian Student Coordinator at AFIT, a civilian contractor at the AFIT Center for Cyberspace Research, and four AFIT Faculty Advisors.

At the Joint Orientation, the Civilian Student Coordinator first welcomed the students to AFIT, followed by a welcome from the Director of Student Services. The Director of SOCHE also welcomed the students to the Summer Research Program. The Civilian Student Coordinator provided a document describing the summer research experience.

The Scholarship for Service Coordinator at the AFIT Center for Cyberspace Research talked with students and spoke about the Cybercorps program and future of cyberspace research. The Scholarship for Service program is a joint effort through the Air Force Institute of Technology and National Science Foundation that offers college graduates in computer science, computer engineering, electrical engineering and mathematics the opportunity to receive advanced graduate education in return for federal service upon completion. These are full scholarship opportunities that also include a stipend, laptop computer, full coverage of books, and traveling expenses for conferences. ${ }^{19}$

Since 2006, the Scholarship for Service program has graduated 50 students with advanced degrees in cyberspace research (98\% graduation rate). The post-graduation employment rate is approximately $99 \%$. The program has received over $\$ 2 \mathrm{M}$ in funding and utilizes close to 40 faculty members that teach students Cyber Defense, Cyber Warfare, and Cyber Operations that they will implement in jobs that are greatly helpful to our country's national defense. Since its inception, the Scholarship for Service program has had a near perfect job placement rate at agencies including the CIA, NSA, NASIC, and MIT Lincoln Laboratories. In addition, several students have enrolled in PhD programs at different universities around the United States to continue their graduate studies.

\section{Introduction of Component \#2: Student Cohorts through Social Activities and STEM- based games}

The second component that we introduced in the 2013 Summer Research Program is Student Cohorts. This component is designed to provide students with the opportunity to develop communication, high ethical standards, and professionalism through written and oral presentations and discussions with fellow students and faculty.

This component introduced social activities and STEM-based games. These activities focused on building student camaraderie and enjoyment, within the context of learning more about STEM careers. This component consisted of team games, weekly lunches (both on and off campus), and an evening kayak trip.

In order to participate in the games, students were asked to form "cohorts" of about 5 students each. Students in a cohort would compete in each game as a team, hopefully building team spirit in activities outside of the laboratory. In order to maintain a control group and to not occupy 
students' time without their advisors' permission, students were given the option to either join a cohort or to not join, with joining contingent upon advisor approval. Of the 43 interns, 23 (response rate: $53 \%$ ) organized into 5 cohorts, and 20 students chose not to join a cohort.

Table 1: Scavenger Hunt Items

\begin{tabular}{|c|c|}
\hline Item & Documentation \\
\hline $\begin{array}{l}\text { Create a valid course plan for an MS degree at } \\
\text { AFIT }\end{array}$ & $\begin{array}{l}\text { Course list signed by faculty } \\
\text { member in that area }\end{array}$ \\
\hline $\begin{array}{l}\text { Create a valid course plan for a PhD degree at } \\
\text { AFIT }\end{array}$ & $\begin{array}{l}\text { Course list signed by faculty } \\
\text { member in that area }\end{array}$ \\
\hline $\begin{array}{l}\text { Description of duties for a teaching assistant at a } \\
\text { school other than AFIT }\end{array}$ & $\begin{array}{l}\text { Paragraph with references, or } \\
\text { print-out of official description }\end{array}$ \\
\hline $\begin{array}{l}\text { Description of duties for a research assistant at a } \\
\text { school other than AFIT }\end{array}$ & $\begin{array}{l}\text { Paragraph with references, or } \\
\text { print-out of official description }\end{array}$ \\
\hline Postings of 3 graduate scholarships in your field & URLs of web pages \\
\hline $\begin{array}{l}\text { Promotion and Tenure guidelines of another school, } \\
\text { as posted online }\end{array}$ & URL of the webpage \\
\hline Find an AFIT MS thesis, then look it up online & $\begin{array}{l}\text { The URL within Defense } \\
\text { Technical Information Center } \\
\text { (DTIC) }^{20}\end{array}$ \\
\hline $\begin{array}{l}\text { Find an AFIT PhD dissertation, then look it up } \\
\text { online }\end{array}$ & The URL within DTIC \\
\hline $\begin{array}{l}\text { Get an AFIT MS thesis prospectus from a current } \\
\text { student }\end{array}$ & Printout or PDF \\
\hline Get an AFIT PhD prospectus from a current student & Printout of abstract or PDF \\
\hline Attend an MS thesis defense (any local school) & $\begin{array}{l}\text { List of questions asked by the } \\
\text { audience at end of defense }\end{array}$ \\
\hline Attend a PhD defense (any local school) & $\begin{array}{l}\text { List of questions asked by the } \\
\text { audience at end of defense }\end{array}$ \\
\hline $\begin{array}{l}\text { Get a publication from an AFIT professor and find } \\
\text { another publication that cites it }\end{array}$ & PDFs or URLs of both papers \\
\hline $\begin{array}{l}\text { Find a publication that has been cited more than } \\
100 \text { times }\end{array}$ & $\begin{array}{l}\text { URL/printout of Google Scholar } \\
\text { page (or similar) for that paper }\end{array}$ \\
\hline The Curriculum Vitae (CV) of an AFIT professor & PDF or printout of first 2 pages \\
\hline Find a poster template from an AFIT professor & Electronic copy of template \\
\hline $\begin{array}{l}\text { Your resume, updated based on critique from your } \\
\text { advisor }\end{array}$ & $\begin{array}{l}\text { Copies of marked-up and revised } \\
\text { resume }\end{array}$ \\
\hline Your resume, before being updated by advisor & Electronic copy of resume \\
\hline $\begin{array}{l}\text { Write up and give a 5-minute update on your } \\
\text { research to your cohort }\end{array}$ & $\begin{array}{l}\text { Written feedback from each } \\
\text { cohort member }\end{array}$ \\
\hline $\begin{array}{l}\text { Give a 5-minute update on your research to an } \\
\text { AFIT professor other than your advisor }\end{array}$ & $\begin{array}{l}\text { Written feedback from the } \\
\text { professor }\end{array}$ \\
\hline $\begin{array}{l}\text { Give a 5-minute update on your research to another } \\
\text { intern who is not in your cohort }\end{array}$ & $\begin{array}{l}\text { Written feedback from the } \\
\text { student }\end{array}$ \\
\hline
\end{tabular}


The first game, a STEM scavenger hunt, was initiated at the joint orientation session from Component \#1. The students were asked to collect items from Table 1 (see Table 1 on previous page). Each item was assigned a point value (usually 5 points each), and the goal was to be the first cohort to 75 points. The collection items were designed to encourage the students to learn about STEM careers by attending defenses, finding opportunities for education or scholarships, and improving their resumes and technical communication skills.

The second game that was planned was a specialized version of the word game "Taboo." In Taboo, in each round, each team picks a clue giver who has to get teammates to say certain words, but the clue giver cannot say any taboo words. In this instantiation, the words to be guessed were all concepts related to STEM or higher education, such as "lab notebook," "letter of recommendation," "simulation," etc. The intent was to get students more comfortable with these concepts by forcing them to talk about them without using the standard definitions.

Aside from the games, Component \#2 included several purely social activities. On weeks when no technical activities were planned, students and advisors were invited to gather for group lunches to socialize. A capstone social activity was provided by SOCHE in the form of a group kayak trip along the Mad River, ending in downtown Dayton. Again, the goal was to provide students with a chance to get to know advisors and other interns outside of a purely academic context.

The assessment plan for the efficacy of these activities was to administer surveys to the interns at the start and end of the summer program. The pre-survey asked about their interest in STEM careers, professional development activities (e.g. resume building), and social activities. The post-survey followed up with similar questions regarding their interest in STEM careers, whether or not they still wanted resume assistance, their plans for further education, and their opinion of the social program.

\section{Introduction of Component \#3: Weekly Seminar Meeting with Outside Presentations of General Interest}

The third component that we introduced in the 2013 Summer Research Program is a Weekly Seminar Meeting. In each meeting, we arranged an outside presentation of general interest, such as jobhunting, resume-writing, information about scholarships and fellowships, and the process to apply to graduate school. This component is designed to provide students with the opportunity to develop and exhibit communication, high ethical standards, and professionalism through a workshop on resume writing, a workshop on poster creation, and a tour provided to SOCHE interns by the Director of the Center for Cyberspace Research (CCR).

In order to keep the students engaged in an ongoing basis, we planned to have an activity of some sort at least once per week. This began with the joint orientation from Component \#1 and concluded with the poster session from component \#4; and in the interim, we alternated between social gatherings and professional development activities (in the form of working lunches). 
The full schedule of activities across all components was:

- Week 1: Joint orientation, with pizza lunch (Component \#1)

- Week 2: Social lunch at Riverscape MetroPark in Dayton, Ohio (Component \#2)

- Week 3: Social lunch at AFIT cafeteria (Component \#2)

- $\quad$ Week 4: Resume workshop (Component \#3)

- Week 5: Social lunch at AFIT cafeteria (Component \#2)

- Week 6: Poster creation workshop (Component \#3)

- Week 7: Social lunch at AFIT cafeteria (Component \#2)

- $\quad$ Week 7: Tour of Center for Cyberspace Research (CCR) (Component \#3)

- Week 8 (evening): Social kayaking trip (Component \#2)

- Week 8: Poster session with sandwich lunch (Component \#4)

The resume writing workshop was held at AFIT, and it featured three invited human resources experts from two local companies, KLSS, Inc., ${ }^{21}$ and Aerospace Professional Development Center (APDC). ${ }^{22}$ KLSS, Inc. is a Woman-Owned Small Business focused on delivering integrated technical and business operations solutions for the federal government since 1997. APDC is located at Wright State University and works with the aerospace and defense industry, federal government, and higher education institutions in Ohio to offer career coaching and other opportunities for students and STEM professionals. The one-hour workshop offered by KLSS, Inc., and APDC covered topics such as how to build a resume, what employers look for, and how to develop professional networking skills. Twelve of the 43 (28\%) students attended; those who attended were extremely engaged and asked a multitude of questions, including feedback on their resumes during the session.

In the one-hour poster creation workshop, an AFIT faculty member discussed key elements to include in a paper, how to communicate technical ideas concisely, and how to physically create and mount the poster.

Since 2002, CCR offers research opportunities to students to conduct defense-focused graduatelevel research. A three-hour tour of the Center for Cyberspace Research (CCR) was held at AFIT, and 12 of the 43 students $(28 \%)$ participated. ${ }^{23}$ The Director of CCR led students on a tour of CCR facilities followed by demonstrations of two current CCR projects. Summer students have the opportunity to work with CCR faculty and civilian contractors on summer research projects and learn about fellowship opportunities that are available in Cyber Security Graduate Programs ${ }^{24}$ funded through the National Science Foundation Scholarship for Service program (also known as Cybercorps). 


\section{Introduction of Component \#4: Poster Session Development, Implementation, and Judging}

The fourth component that we introduced in the 2013 Summer Research Program is a Poster Session. The Poster Session is open to members of the public as well as to members of the DOD (faculty, students, and staff). This component is designed to provide students with the opportunity to develop and exhibit strong analytical skills, communication, high ethical standards, and professionalism through poster development, oral presentations, and discussions with fellow students, industry experts, and faculty.

The poster session provided students with an opportunity to create a research poster and present the results of the engineering experiences they have gained. Participation in the poster session was voluntary. Since this is a first time experience for many of our undergraduate students, we have taken the following detailed steps to ensure our students understood the poster presentation process.

Two weeks prior to the poster session, a presentation was offered to the students to explain how to prepare, organize and format a poster for the session. Design tips were provided. These tips consisted of planning, layout, color, text and font, and visuals. For planning, the students were told to start by writing down everything. Planning also included drawing a sketch of the poster on paper with sections and headings. This approach would help with proofreading, eliminating unnecessary information and setting up attention grabbers for the audience. Once planning is complete, the students were encouraged to move their designs to a computer program for improving the layout.

The poster layout consisted of setting up the headings and subheadings. The students were given examples on how the text size is critical for headings. The poster layout should be well organized and divided into sections. This organization ensures a good balance of the information and helps to keep it simple. By laying out the poster with a computer program, the students were able to see how adding graphics and photographs could help explain their research to the audience. A word of caution was provided on the level of information presented and how to avoid a clustered poster. To complete the advice on poster layout, the students were provided reasons for organizing the poster in a sequential or column-and-row flow. A major benefit is that this latter approach is that it helps the attendees and judges follow the flow of information.

The final three tips provided for poster presentation cover the color, text and font, and visuals. These three tips are based on what the audience will be able to view on the poster. The biggest concerns for colors are clarity and being soft on the eyes to reduce strain. The tip for text and font is having consideration for the size and type. The students were told to make text readable from one to three meters. The font type should be easy to read so the reader can pick up information without have to interpret the font. Visuals consist of graphics, photographs, and diagrams. These are a quick way to show your results and experimental data. The students were instructed to add these where necessary. They were suggested to use software packages to create graphics and diagrams. For photos and images, it was suggested to enlarge and crop these in order to focus on relevant parts. A final note was on ensuring the visuals are clear and finished with good quality.

The location for the poster session was provided at the working lunch so the students could inspect the area in advance. The poster session location was based on space need for students, their advisors, visitors, and the ease of access for the students around the posters. The students were provided a setup time and told the time frame of the session would last for one hour. 
The one-hour poster session took place in an open room setting at the Atrium of the institution's School of Civil Engineering. This atrium provided ample space for the students with plenty of room between each poster. This allowed the audience to review the posters without being clustered or crowded. During the poster session, the students were provided easels and poster boards. The baseline poster materials provided consisted of 8.5 inch x 11 inch papers for the slides.

Attendees at the poster session included AFIT faculty, the Director of Choose Ohio First, ${ }^{25}$ the Director at SOCHE, the Senior Director at SOCHE, and SOCHE's marketing intern. Choose Ohio First Scholarship Program is “part of [Ohio's] strategic effort to significantly strengthen Ohio's position in world markets such as aerospace, medicine, computer technology, and alternative energy. The Choose Ohio First Scholarship Program awards Ohio colleges, universities and their business partners that have developed innovative academic programs to recruit and retain more Ohio students into STEMM fields." 25

Three Poster Session judges were chosen from the faculty in the six departments at this institution. None of the judges had students presenting a poster. The judges were provided with a poster session rubric to evaluate each poster. Based on the number of posters in the session, the judges interviewed each student within the one-hour timeframe. The poster session attendees were very interested in the research topics and provided great feedback on the student's research, presentation skills and the importance of presenting research. The judges tallied up the scores for each poster based on the rubric criteria and provided their selection for "Posters of Excellence" winners.

Table 2 provides a list of the posters, number of students presenting the poster, gender and their department. This year seven posters were presented at the session (participation rate: 16\%). Two presentations were co-authored by two students. There were six male and three female authors.

The students were members of the following Departments at AFIT: Electrical and Computer Engineering, Aeronautics and Astronautics, Systems and Engineering Management, and Operational Sciences. Attendees at the poster session included faculty from the four departments, Senior Director and Director of SOCHE, a Director from Choose Ohio First for the Ohio Board of Regents.

As shown in Table 2, the poster titles are: 1) "Radio Tomographic Imaging", 2) "Data Leakage Based Anomaly Detection for Critical Infrastructure Protection", 3) "Fast Detection and Quantification of Dangerous Water Pollutants with Biosensors", 4) "An Agent-based Model of Fire Ignition Resulting from Ballistic Impacts", 5) "Make Screen Configuration Optimization", 6) "Analysis of the Horseshoe Vortex", and 7) "Peptide Nanotubes for Organophosphate and Carbamate Detection". 
Table 2. Posters in the 2013 Summer Poster Session

\begin{tabular}{|c|c|c|c|c|}
\hline $\begin{array}{l}\text { Poster } \\
\text { Number }\end{array}$ & Poster Title & Students & Gender & Department \\
\hline 1 & Radio Tomographic Imaging & 1 & Male & $\begin{array}{l}\text { Electrical and } \\
\text { Computer } \\
\text { Engineering }\end{array}$ \\
\hline 2 & $\begin{array}{l}\text { Data Leakage Based Anomaly } \\
\text { Detection for Critical } \\
\text { Infrastructure Protection }\end{array}$ & 2 & Males & $\begin{array}{l}\text { Electrical and } \\
\text { Computer } \\
\text { Engineering }\end{array}$ \\
\hline 3 & $\begin{array}{l}\text { Fast Detection and } \\
\text { Quantification of Dangerous } \\
\text { Water Pollutants with } \\
\text { Biosensors }\end{array}$ & 1 & Female & $\begin{array}{l}\text { Systems and } \\
\text { Engineering } \\
\text { Management }\end{array}$ \\
\hline 4 & $\begin{array}{l}\text { An Agent-based Model of Fire } \\
\text { Ignition Resulting from } \\
\text { Ballistic Impacts }\end{array}$ & 1 & Male & Operational Sciences \\
\hline 5 & $\begin{array}{l}\text { Make Screen Configuration } \\
\text { Optimization }\end{array}$ & 1 & Male & Operational Sciences \\
\hline 6 & $\begin{array}{l}\text { Analysis of the Horseshoe } \\
\text { Vortex }\end{array}$ & 2 & $\begin{array}{l}\text { Male, } \\
\text { Female }\end{array}$ & $\begin{array}{l}\text { Aeronautics and } \\
\text { Astronautics }\end{array}$ \\
\hline 7 & $\begin{array}{l}\text { Peptide Nanotubes for } \\
\text { Organophosphate and } \\
\text { Carbamate Detection }\end{array}$ & 1 & Female & $\begin{array}{l}\text { Systems and } \\
\text { Engineering } \\
\text { Management }\end{array}$ \\
\hline
\end{tabular}

The seven topics covered by the posters were:

1. In Poster \#1, the student presented experimental results of real-time radio tomographic imaging (RTI), which allows for imaging of humans through foliage and concrete walls. The students showed the effectiveness of the method for real-time surveillance.

2. The research presented in Poster \#2 described a detailed process for integrating a high performance content-control appliance into a process control system commonly deployed in a water treatment facility. The students' results were transitioned to industry.

3. The research presented in Poster \#3 demonstrated that microbial fuel cells can be used to detect recalcitrant organic chemicals and has the potential to monitor water quality.

4. The research in Poster \#4 addressed the problem of prevention of potential onboard fires in an aircraft resulting from a high-velocity projectile impact. The students developed an impact fragmentation model to simulate this problem.

5. Poster \#5 focused on Man-Portable Air-Defense Systems as the weapon of choice and live-fire arena testing as the experimental data source. In this project, students built a simulation infrastructure to display the fragment distribution of test events. 
6. Poster \#6 addressed the problem of improving the efficiency of gas turbine engines to improve fuel savings for DOD and Air Force systems. In this project, students developed a method to measure heat transfer coefficients.

7. Poster \#7 presented research on a biosensor for the detection of nerve agents and pesticides. The students were able to demonstrate the viability of using the biosensor to quickly, accurately, and inexpensively detect low concentrations of gases.

Immediately following the poster session, two faculty members gave feature talks to participating students, judges, and attendees. These two talks focused on poster presentations and reasons why students should consider attending graduate school. The briefing on poster presentation was provided by a junior faculty member at AFIT. Using a recently published poster, the faculty member gave a presentation on why posters are important to showcase your research. The presentation was based on setting up or formatting posters. The speaker provided details on how the member used this information to design their posters for conferences and students participated in a question and answer session. A break between the speakers provided the opportunity for those in attendance to obtain lunch and prepare for the next speaker. The second presentation provided by a full professor focused on graduate school education. This presenter's talk was based on the faculty member's experience with graduate students at two institutions. A key portion of the presentation discussed important considerations for looking at a graduate program and some pitfalls to avoid. The students were very inquisitive about the professor's experiences and discussed their thoughts on why they are or are not considering applying to a graduate program.

Following the feature talks, an AFIT faculty member and Director of SOCHE announced the poster session winners. Each winner was provided a "Poster of Excellence" certificate. The other participants were provided participation certificates. After handing out the certificates, the closing remarks were provided by Director of SOCHE.

\section{Results and Findings: Pre-survey and post-survey}

Pre-surveys and post-surveys were sent to all 43 interns. We will refer to these as Surveys A and B, and they were returned by 14 (33\%) and 8 (19\%) students, respectively. Component \#2 was assessed by asking students if they were interested in participating in social activities as part of the internship. Of those who responded, $71 \%$ said they were interested in Survey A, whereas only $57 \%$ said yes in Survey B. This is surprising, given the extremely high participation in the group kayaking activity. This may indicate that the social lunches need to be refined to make the activities more engaging, rather than being simple unstructured gatherings. In the supplementary typed comments, many students expressed an interest in sports activities, and one suggested inviting local businesses to the activities to further increase the networking opportunities.

The more detailed questions in Surveys A and B about STEM career plans related strongly to Component \#3, though to a lesser extent to Component \#2, since it also related to motivation and understanding of STEM careers. Both surveys asked the following questions:

Q1: I plan to graduate with a major in a STEM field.

Q2: I am uncertain about my major. 
Q3: I plan to attend graduate school in a STEM field.

Q4: I plan to attain a Ph.D. in a STEM field.

Q5: I feel confident in my research area knowledge.

Q6: I understand the difference between graduate and undergraduate programs to study.

Q7: I understand the avenues for obtaining funding for graduate work.

Responses were given via a 5-point Likert scale. We compared the results for each question using a T-test, which determines whether or not two distributions can be modeled as having the same mean. Due to the relatively small number of responses, we analyzed the surveys with a relatively high significance level (alpha) of 0.25 . The T-test results were that there was a statistically significant increase in the mean in Q3 (4.00 to 4.38) and in Q4 (3.15 to 3.43). There was also a statistically significant increase in the mean in Q1 (5.00 to 4.88); however, all 14 respondents replied with a " 5 " in Survey A and only a single student in Survey B gave a lower rating, so this is not a noteworthy decrease. The other 4 questions did not indicate a statistically significant change. The interpretation is that the students' motivation to further pursue STEM careers was increased, but their understanding of avenues of doing so did not appreciably increase. This implies that a greater focus is needed in the future on increasing participation in the professional development activities.

For both Component \#2 and Component \#3, we observed that it was extremely difficult to get students to participate in activities. This ranged from the games to the lunches to the resume building workshop to the poster session. The only well-attended events were the orientation that included a free pizza lunch and the kayak trip. This may be in part because students felt like they needed advisor approval to participate, so next year we will be explicitly asking all advisors in advance to indicate whether or not their students have permission to attend (and advisors can specify a subset of events if they choose). The lunches were also held in locations that were conducive to small group gatherings but not global interactions, so we will seek establishing a regular, larger venue for such activities next year. The games in particular were unexpectedly unpopular - the scavenger hunt only drew responses from one group; and the Taboo game was not implemented because not enough students were present at any of the later lunches to enable a feasible game. Again, we will seek to remedy this by asking advisors for permission for the students to participate, and maybe even to actively encourage the students to do so.

For Component \#4, we had seven poster presentations (with a total of nine students) who volunteered to present their summer research. For two posters, two students worked together to present their research topic. The students were well prepared for their presentations. They used tips provided during the working luncheon held three weeks prior to the poster session. The baseline poster design appeared in all the presentation. Some students had laminated posters and working prototypes of their experimental research on display. The judges were extremely proud of the students and had a great time going around inspecting the posters. Using the poster rubric, the three judges were able to compare each poster with a standardized set of rules. It provided an excellent guide for the three judges. The judges selected three posters as "Posters of Excellence." 
Along with the poster session for Component \#4, we included a working lunch to brief the students on poster presentations and graduate school education. This served as an opportunity to interact with the students for a final activity. The working lunch gave the students an opportunity to discuss their opinion on poster presentations and to hear from a junior faculty member about their poster presentation experience at a major conference. Topics covered during this briefing were presentation skills, setting up or formatting posters and how they use this information to design their poster for conferences. The faculty member completed the briefing with a demonstration on how they present information at a poster session. The second briefing during the working lunch focused on the importance of graduate education. We did not want the summer students to leave AFIT without taking the opportunity to explain why attending graduate school is so important for their career progression. The brief was provided by a full professor who had experience at several universities. It was an interactive brief were the professor discussed a topic and opened up to answer questions from the students. The topics were centered on selecting a graduate program, interacting with advisors and pitfalls to avoid while at graduate school. As the final activity, the poster session and working lunch was well received. This initial poster session definitely established a good foundation to continue this during future AFIT Summer Intern Programs.

\section{Results and Findings - Rehire Survey for Participating Students in 2012 Summer Program and 2013 Summer Program}

A "Rehire Survey" was developed and sent to the same 10 interns who participated in internships at AFIT in both 2012 (21\% of participants in 2012) and in 2013 (25\% of participants in 2013). We will refer to this survey as Survey $C$, and it was completed by 6 (response rate: 60\%) of the students. Responses were also provided on a 5-point Likert scale, with 5 being the most positive rating.

Regarding Component \#2, when asked to rate the social program for both years, the mean response provided by the students improved from 3.67 in 2012 to 4.33 in 2013. When asked if they would like more or less social programming in the future, five students answered "about the same," and one student asked for significantly more. These results indicate that the increase in social programming was approved of, and that the 2013 level was roughly the right level.

Survey $\mathrm{C}$ included several questions relating to the professional activities from Component \#3. When asked to rate their gain in non-technical but work-related professional experience for both years, the mean response reported by the students improved from 3.67 in 2012 to 4.17 in 2013. When asked if they would like more or less professional programming in the future, five students answered "about the same," and one student asked for slightly more. These results indicate that the increase in professional programming was approved of, and that the 2013 level was approximately ideal.

\section{Discussion}

Each of the four components introduced in the 2013 Summer Research Program provides participating students with the opportunity to develop and exhibit the key attributes of strong analytical skills, communication, high ethical standards, and professionalism. First, the Joint Orientation provided students with an opportunity to communicate their background and intended 
project to fellow students, participating faculty, and DOD personnel. These opportunities continued for students participating in the Student Cohorts, Weekly Seminar, and Poster Session. The Poster Session provides an opportunity for the students to exhibit their technical skills and research knowledge that they have gained to fellow students, participating faculty, SOCHE leaders, DOD personnel, and the Director of Choose Ohio First.

Actions to improve participation of students in 2014 Summer Program is to request that the Faculty Advisor pay for lunch to attend the broadening meetings in each component, which is about one to two hours per week. Currently, the faculty advisor pays for the research of the student, who has only a 30-minute unpaid lunch break. We believe that offering the students an opportunity to attend these broadening activities while being paid will increase the percentage of students who see the benefits of these new components.

\section{Conclusions}

This paper presents first steps in the transformation of all internships in the undergraduate STEM Summer Research Program in the federal government at the Air Force Institute of Technology (AFIT) to prepare students for engineering careers in the $21^{\text {st }}$ century. Starting in summer 2013, students are now provided with four career broadening programs that are informed by student survey results in 2012. Because of government restrictions, student participation is voluntary. The components presented in this paper are (A) A joint orientation; (B) Student cohorts through social activities and STEM-based games; (C) A weekly seminar meeting; and (D) A Poster Session.

In this paper, we described the importance of the four new career-broadening components to transform the internships at AFIT to prepare students for engineering careers in the $21^{\text {st }}$ century. Our new results and findings of the assessment of the 2013 Summer Research Program show that the students respond favorably to the 2013 Program and its components. Students who participated in both the 2012 program and the 2013 program responded that the level of programming introduced by the four components was well received.

To increase participation by the students in future summer programs, starting in 2014, we will offer the faculty an opportunity to pay students for the time (approximately one hour per week) to participate in the four components. With the opportunity to earn additional income through participation in the four new components, we anticipate increased participation. We look forward to partnering together to obtain feedback from the students to improve the students' research experiences at our DOD institution. In this way, we hope that these efforts produce students who are well prepared for $21^{\text {st }}$ century engineering careers.

\section{Acknowledgements}

The authors thank Dr. Heidi Ries, Dean for Research at AFIT, for discussions throughout this project. The authors wish to thank Mr. Robert M. Hoelzel, Scholarship for Service Coordinator of the Center for Cyberspace Research; Mr. Richard Gammon, Director of Student Services; and Ms. Briana Hervet, Director of Choose Ohio First, for discussions and for their feedback on this paper. We also thank Prof. Raymond Hill, Prof. Willie Harper, Prof. Rusty Baldwin, Mr. Juan Lopez Jr., Prof. Mark Goltz, and Maj James Rutledge for the descriptions of the posters prepared 
by their students. We thank Mr. Bradley Paul, Chief of Integrated Circuits and Microsystems, Sensors Directorate, Air Force Research Laboratory, for information about Palace Acquire and the Pathways program offered by the U.S. Air Force.

Partial support for this work was provided by the National Science Foundation NSF ADVANCE under Award \# 0810989. Any opinions, findings, conclusions, and recommendations expressed in this material are those of the authors and do not necessarily reflect the views of the National Science Foundation.

\section{Bibliography}

1. Engineer of 2020: Visions of Engineering in the New Century. Online: http://www.nae.edu/Programs/Education/Activities10374/Engineerof2020.aspx.

2. J. Drennan, M. Y. Lanzerotti, M. Varga, S. J. Creighton, D. Langley, D. L. Cahill, "Developing Best Practices for an Undergraduate STEM Summer Research Program in a Government Institution through a Higher Education Partnership," ASEE 2014

3. AFOSR: Awards to Stimulate and Support Undergraduate Research Experiences (ASSURE). Online: http://www.wpafb.af.mil/library/factsheets/factsheet.asp?id=9333

4. National Science Foundation Research Experiences for Undergraduates. Online: http://www.nsf.gov/crssprgm/reu/reu_search.jsp.

5. SMART Scholarships. Online: www.smart.org.

6. Air Force Civilian Careers: Students. Online: http://afciviliancareers.com/content/students/.

7. National Defense Science \& Engineering Graduate Fellowship (NDSEG). Online: ndseg.asee.org.

8. SOCHEIntern. Online: www.socheintern.org.

9. Air Force Civilian Careers. Online: http://afciviliancareers.com/content/students/.

10. USAJobs. Online: https://www.usajobs.gov/JobSearch/Search/GetResults?Keyword=pathways\&Location=\&search.x=0\&search.y $=0$.

11. PALACE Acquire. Online: http://afciviliancareers.com/careers/pathways/students/palace-acquire/.

12. Summer Faculty Fellowship Program (SFFP). Online: $\underline{\text { sffp.asee.org. }}$

13. CyberCorps: Scholarship for Service. U.S. Office of Personnel Management. Online: http://www.sfs.opm.gov.

14. Oak Ridge Institute for Science and Education (ORISE). Online: http://orise.orau.gov/about-orise/default.aspx.

15. LEADER Consortium Mini-Grant National Science Foundation Award \#0810989, Online: http://www.wright.edu/leader.

16. National Science Foundation. Online: www.nsf.gov.

17. Air Force Institute of Technology (AFIT). Online: www.afit.edu.

18. Southwestern Ohio Council for Higher Education (SOCHE). Online: www.soche.org.

19. Application for Admission. CCR. Online: https://www.afit.edu/ccr/CyberCorp/cybercorpsapp/index.cfm.

20. Defense Technical Information Center. (DTIC). Online: www.dtic.mil.

21. KLSS. Online: http://www.klssinc.com.

22. Aerospace Professional Development Center at Wright State University (APDC). Online: http://www.ohioaerospacecareers.org.

23. AFIT Center for Cyberspace Research. Online: http://www.afit.edu/en/ccr/.

24. AFIT CyberCorps. Online: http://www.afit.edu/ccr/CyberCorp/Default.cfm.

25. Choose Ohio First (Ohio.gov). Online: http://www.chooseohiofirst.org. 